\title{
ASPEN, ELK AND WOLVES IN YELLOWSTONE: ARE ASPEN RECOVERING SINCE THE RETURN OF WOLVES?
}

\author{
LUKE E. PAINTER $\uparrow$ WILLIAM J. RIPPLE $\uparrow$ ROBERT L. BESCHTA \\ OREGON STATE UNIVERSITY $\uparrow$ CORVALLIS
}

ERIC J. LARSEN $\bullet$ UNIVERSITY OF WISCONSIN $\uparrow$ STEVENS POINT

\begin{abstract}
$\uparrow \quad$ AbSTRACT
We assessed aspen stand conditions in 2012 in 87 stands randomly located across the northern winter ungulate range of Yellowstone National Park (YNP), and compared these data to baseline conditions measured in 1997-98 shortly after wolves were reintroduced. In 1997-98, browsing rates (the percentage of leaders browsed annually) in aspen stands were consistently very high, averaging $88 \%$ of stems browsed; only $1 \%$ of young aspen in sample plots were taller than $100 \mathrm{~cm}$ and none were taller than $200 \mathrm{~cm}$, the height at which aspen begin to escape from browsing by elk. Using the same methods in 2012, 17 years after wolf reintroduction, browsing rates were much lower averaging $44 \%, 34 \%$ of sampled young aspen were taller than $100 \mathrm{~cm}$, and $5 \%$ taller than $200 \mathrm{~cm}$. Mean heights of young aspen in 2012 were inversely correlated with browsing intensity ( $R 2=0.64, p=<0.001$ ), but heights were not associated with current annual growth in height (an index of site productivity; $\mathrm{R} 2=0.02, \mathrm{p}=0.2$ ). Some stands were still heavily browsed in 2012 with wide spatial variation across the range and between stands, but on average, browsing declined after 2003 followed by a relatively rapid increase in height of the tallest saplings. The greatest change was on the eastern side of the northern ungulate winter range, corresponding with recent changes in elk population distribution. Recent growth of young aspen into tall saplings will likely result in the regeneration of overstory trees and the persistence of aspen stands into the future, though aspen recovery will take many years and some stands may continue to decline. These results support the
\end{abstract}

hypothesis that a trophic cascade following the return of wolves to Yellowstone has begun to reverse the decades-long trend of aspen decline on the northern range.

\section{$\downarrow \quad$ INTRODUCTION}

Aspen (Populus tremuloides) stands were unable to regenerate and declined in northern Yellowstone National Park (YNP) in the 20th century due to intensive browsing of young aspen by elk (Cervus elaphus) (Romme et al. 1995, NRC 2002, Barmore 2003). Through their effects on elk population densities and foraging behavior, wolves (Canis lupus) can play a role in the relationship between elk and aspen (White et al. 1998), and the reintroduction of wolves to YNP in 1995-96 (Smith and Bangs 2009) provided an opportunity to observe this interaction. Larsen and Ripple (2001, 2005), working on the Yellowstone northern ungulate winter range ("northern range") in 1997-98, found that about $90 \%$ of young aspen leaders were browsed annually, and most young aspen were kept shorter than $100 \mathrm{~cm}$ by repeated browsing, preventing stand regeneration. Through analysis of tree cores, they found that the historical decline of aspen tree recruitment (i.e., growth of young aspen into trees) roughly coincided with the time that wolves were eliminated in the park, supporting the idea that the decline of aspen was due to a trophic cascade following the loss of wolves (Larsen and Ripple 2003). Subsequent research by Ripple and Beschta $(2007,2012)$ in 2006 and 2010 supported the trophic cascade hypothesis, with 
evidence that aspen were beginning to recover in the eastern part of the northern range following the return of wolves. However, Kauffman and others (2010) found no evidence in 2004-07 that aspen were recovering in northern Yellowstone, and concluded that elk herbivory was still intensive enough to suppress aspen regeneration. These studies used different methods (Beschta and Ripple 2011) and sampling was limited to either a small number of stands (Kauffman et al. 2010) or to one portion of the YNP northern range (Ripple and Beschta 2012). More research is needed to explore the developing relationship between aspen, elk and wolves in the northern Yellowstone ecosystem.

In the eastern portion of the YNP northern range elk densities have declined to relatively low levels in recent years (White et al. 2012), so changes in aspen are likely in at least some areas, but aspen stands did not recover in the 1950s and 1960s despite more than two decades of relatively low elk population densities when elk and bison (Bison bison) herds were annually culled (Yellowstone National Park 1997, Beschta and Ripple 2011). Trophic cascades from wolves to elk to aspen have been observed in other ecosystems (White et al. 2003, Hebblewhite et al. 2005, Beschta and Ripple 2007); these have varied in the strength of the cascade, and in the importance of other factors affecting aspen regeneration (Eisenberg et al. 2013). In northern Yellowstone, the history of exceptionally high elk population densities, complete absence of wolves, and nearly complete absence of aspen regeneration (Wagner 2006) makes the area exceptionally well-suited for a natural experiment to detect the influence of wolves on aspen.

The 1997-98 research of Larsen and Ripple (2003, 2005) provided a baseline for aspen conditions shortly after wolf reintroduction. In the summer of 2012, we used this baseline to assess changes in browsing rates and heights of young aspen over time in 87 stands randomly selected across the YNP northern range within the park boundary, compared to 79 of the same stands sampled by Larsen in 1997-98. The ability to compare aspen conditions over a 14-year span of time is a distinct advantage of this study. We collected additional data as well, for a more detailed analysis of aspen stand conditions in 2012, and to account for factors other than browsing that could affect aspen growth such as differences in stand productivity.

\section{MeTHODS}

Larsen randomly located 93 aspen stands on the northern range to assess the age distribution of aspen trees, and collected data on young aspen in 79 of those stands. Between July 24 and September 1, 2012, we revisited 76 of these 79 stands (three did not have GPS locations), plus 11 more stands from the 1997-98 study for a total of 87 stands sampled in 2012 . We excluded one stand on a steep scree slope, which previous research has shown to inhibit ungulate browsing as a partial exclosure (St. John 1995, Larsen and Ripple 2005). A stand was defined as a group of aspen separated from other aspen by $>30 \mathrm{~m}$. We recorded the GPS location, slope, aspect, elevation, distance to roads, distance to conifer forest, plant community type (xeric, mesic, or wet), and topographic position (riparian or upland; see Ripple and Beschta 2007, 2012). Conifer cover in aspen stands was classified as 0 (none), 1 (few, little cover), 2 ( $<$ half covered), or 3 ( $>$ half covered). As an index to ungulate use of the area, ungulate fecal piles, including elk, bison, deer (Odocoileus spp.) and pronghorn (Antilocapra americana) were counted in four $2 \times 50 \mathrm{~m}$ plots spaced $7 \mathrm{~m}$ apart, placed outside of the stand perimeter in the nearest open area used by ungulates accessing the stand. Sampling plots for fecal piles were not placed within aspen stands because many stands were wet with very dense vegetation, some with standing water for part of the spring and summer. Placing the scat plots outside of the stands resulted in a much more consistent probability of scat detection, and a useful index to relative ungulate densities across the landscape. A viewshed index was calculated from the average of the distance at which view was obstructed, (to $900 \mathrm{~m}$, the limit of the laser rangefinder) in each of the four directional quadrants (Ripple and Beschta 2006), from the point of origin of the ungulate scat plots.

Most stands were relatively small and each stand was sampled with a 2x30 m plot (Kay 1990), beginning at the closest tree on the perimeter of the closest stand to the GPS location, and extending toward the centroid of the stand. Plots were not duplicates of the 1997-98 plots, but were in the same aspen stands. An aspen tree is defined as having a diameter-at-breast-height $(\mathrm{dbh})>5 \mathrm{~cm}$; aspen $<5 \mathrm{~cm}$ $\mathrm{dbh}$ are called young aspen, and young aspen $200 \mathrm{~cm}$ tall or taller are saplings. In each sampling plot we recorded the dbh of all aspen trees and saplings, and all other species of trees taller than $200 \mathrm{~cm}$. For young aspen in the sampling plot, we recorded the height and browsing status (browsed or not) of the tallest leader for fall 2012 (top height), spring 2012, and spring 2011 , as indicated by bud scars and browsing scars (Keigley and Frisina 1998). If the righthand side of the 
plot $(1 \times 30 \mathrm{~m})$ had 25 or more aspen sprouts older than one year, sampling of young aspen was ended with this reduced plot. If the entire $2 \times 30 \mathrm{~m}$ plot had less than 15 aspen sprouts, the plot was extended in increments of $30 \mathrm{~m} 2$ to reach a count of at least 15 . We also located the five tallest young aspen in the stand (within $60 \mathrm{~m}$ of the sampling plot) and used plant architecture to assess height and browsing status over all previous years for these five tallest young aspen (Ripple and Beschta 2012).

In the 1997-98 aspen data, the heights of young aspen in sampling plots were classified as taller than $100 \mathrm{~cm}$ or $200 \mathrm{~cm}$. We compared between $1997-$ 98 and 2012 the mean percentage of young aspen in these two height categories, and the mean percentage of stems browsed (browsing rate), using bootstrapping to test for differences and generate confidence intervals. Browsing rate calculations did not include aspen $>200 \mathrm{~cm}$ tall, following Larsen (2001). Most browsing by elk occurs at heights below $200 \mathrm{~cm}$, so taller shoots could bias the result if included. Values were first calculated within a plot, and then averaged across plots for a grand mean. Bootstrapping was used because the distribution of the data was not suitable for distributional analysis methods. A 95\% confidence level was used to assess statistical significance for all tests.

Data collected in 2012 permitted a more detailed analysis of browsing intensity and young aspen height. The 1997-98 data did not identify sprouts new that summer that had not been exposed to winter browsing, so the browsing rate underestimated the true browsing rate in plots that contained new sprouts. For further analysis of 2012 data we calculated an adjusted browsing rate that did not include new sprouts, resulting in a slightly higher browsing rate in plots that had new sprouts than was used in the comparison with 1998. As an index of site productivity the mean leader length or current annual leader growth was calculated as the difference between spring height and fall height, averaged across the sampling plot. Confidence intervals and tests for differences for mean height, leader length, and browsing rates were calculated using t-statistics, as the 2012 data were approximately normally distributed and less skewed than the 1998 data. Multiple regression was used to test for the significance of leader length, browsing rate, and other site variables as explanatory variables for the average height of young aspen, with natural logarithm transformations where needed to meet the assumption of constant variance. Coefficients were tested for significance using extrasums-of-squares F-tests. The fit of the models was also assessed using the coefficient of determination (R2).

\section{$\uparrow \quad$ PRELIMINARY RESULTS}

Compared to $1997-98$, browsing rates of young aspen were significantly lower in 2012, the percentage taller than $100 \mathrm{~cm}$ or $200 \mathrm{~cm}$ was much greater, and both browsing and height had greater variation (Table 1). Recruitment of tall young aspen $>100 \mathrm{~cm}$ and saplings $>200 \mathrm{~cm}$ had increased compared to 1997-98, with a much higher of percentage of plots containing at least one young aspen in these height categories (Figure 1).

Table 1. Summary of young aspen browse rates and heights in $1997-98$ and 2012 , with $95 \% \mathrm{CI}$ in parentheses.

\begin{tabular}{l|cccc} 
Years & $\%$ Browsed & $\% \geq 100 \mathrm{~cm}$ & $\% \geq 200 \mathrm{~cm}$ & $\mathrm{n}$ \\
\hline $1997-98$ & $88(84,91)$ & $1(0.5,2)$ & 0 & 79 \\
2012 & $44(39,49)$ & $34(28,40)$ & $5(3,8)$ & 87
\end{tabular}

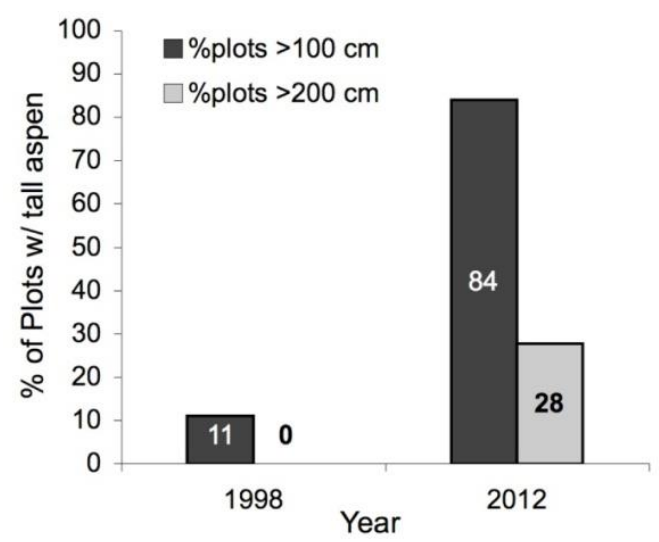

Figure 1. Percentage of samplings plots with at least one young aspen $>100 \mathrm{~cm}$ or $>200 \mathrm{~cm}$ tall or taller.

These results show that aspen have begun to recover in northern Yellowstone, but new saplings were small, most $<3 \mathrm{~cm} \mathrm{dbh}$, and there were no trees in sampling plots smaller than $27 \mathrm{~cm}$ dbh indicating a large gap in recruitment. This gap is the legacy of past conditions, when there were no saplings (Figure 1) and no recruitment of aspen trees. Today, the new saplings are tall enough to escape from elk browsing and are likely to replace dying overstory trees, thus ensuring the persistence of northern range aspen stands into the future (Figure 2). This recovery is in an early stage, which may explain why Kauffman and others (2010) did not find recruiting saplings with limited sampling in 2004-7.

Ripple and Beschta (2007, 2012) used a method of measuring the five tallest saplings in a stands, a method more likely to detect the beginnings 
of aspen recovery. We also measured the five tallest saplings in each stand and found that $46 \%$ of stands had one or more taller than $200 \mathrm{~cm}$ in the spring of 2012 , and $25 \%$ of stands had five or more saplings taller than $200 \mathrm{~cm}$, a strong indication that the stand will successfully regenerate by replacing overstory trees (Kay 2001). Most of these tall saplings originated after 2003, an indication that survival and heights of young aspen have recently increased, but this change would have been difficult to detect by random sampling when Kauffman and others did their research.

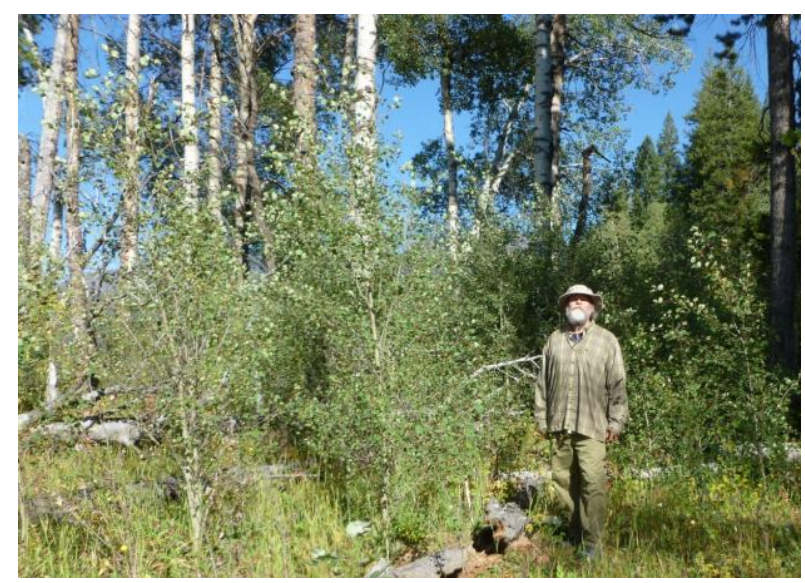

Figure 2. Aspen stand in northern Yellowstone showing overstory aspen trees and young saplings. Lack of intermediate ages and sizes classes is due to the legacy of lack of recruitment due to suppression by herbivory; young saplings in this stand are now taller than the normal browse level of elk and thus likely to grow into new trees.

Could the recent changes in aspen from decline toward recovery be the result of changes in climate? The long-term trend in the region has been toward milder, shorter winters with less snowpack, and dry hot summers (Wilmers and Getz 2005, McMenamin et al. 2008), conditions that would be likely to inhibit aspen recovery due to increased herbivory and drought stress (Brodie et al. 2011, Hanna and Kulakowski 2012). A longer growing season could cause greater annual height growth, contributing to recovery, but if that were the cause of aspen recovery we would expect to find an association between the average length of annual leader growth in a stand and the average height of young aspen. The relationship between leader length and height was very weak $(\mathrm{R} 2=0.02, \mathrm{p}=0.2)$, but there was a strong inverse relationship between browsing rate (averaged over 2011-12) as an explanatory variable for height $(\mathrm{R} 2=0.64, \mathrm{p}<0.001)$. Differences in height between stands appeared to be driven primarily by the amount of browsing, with differences in rates of growth coming into play only where browsing has been reduced. None of the other site variables we collected were statistically significant as explanatory variables for stand browsing rates or heights of young aspen.

In 1997-98, young aspen in nearly all stands experienced high browsing rates and were relatively short, but this was not the case in 2012. After adjusting browsing rates by removing new sprouts from the analysis, in 2012 about $40 \%$ of stands had browsing rates greater than $60 \%$, and remained short with little variation in height among stands, an indication of suppression of height by browsing. The remaining $60 \%$ of stands with browsing rates from $0-60 \%$ showed increasing variation in height, with the tallest heights and greatest variation associated with lower browsing intensity. Browsing rates were generally lower and heights taller on the eastern side of the northern range, which is consistent with recent trends in elk population distribution (White et al. 2012). On the eastern side of the range elk population densities have dropped considerably in recent years, with much less change on the western side of the range. Our scat counts showed the same trend, with an overall reduction compared to surveys done in 1999 (Ripple et al. 2001) when scat counts ranged about 20-40 piles $/ 100 \mathrm{~m} 2$, and strong contrasts across the range in 2012 with the lowest elk scat densities in the eastern part of the range (Table 2). Our East, Central and West sectors follow the same divisions as the Upper, Middle and Lower Inside sectors of White and others (2012). Bison scat showed the opposite trend, with the greatest density in the eastern sector reflecting the large herds of bison that gather there in summer. Willow (Salix spp.) and cottonwood (Populus angustifolia, $P$. trichocarpa) are browsed by bison in the Lamar Valley area, compensating for some of the reduction in elk herbivory and weakening the effect of a trophic cascade from wolves to woody plants (Painter and Ripple 2012), and bison may have a similar effect on aspen.

Table 2. Mean elk and bison scat densities in sectors of the Yellowstone northern range in 2012, with $(95 \% \mathrm{CI})$.

\begin{tabular}{l|cc} 
Sectors & $\begin{array}{c}\text { Elk pellet } \\
\text { piles } / 100 \mathrm{~m}^{2}\end{array}$ & $\begin{array}{c}\text { Bison scat } \\
\text { piles } / 100 \mathrm{~m}^{2}\end{array}$ \\
\hline East & $4(3,6)$ & $11(9,14)$ \\
Central & $11(7,15)$ & $7(5,9)$ \\
West & $17(11,22)$ & $0.7(0.4,1)$
\end{tabular}

The spatial distribution of elk across the northern range (White et al. 2012), lower in the east and greater in the west (Table 2) appears to have been the most important factor influencing aspen herbivory, suggesting that changes in elk population density have 
been driving aspen recovery. The fact that a general aspen recovery did not occur without substantial reductions in elk numbers, suggests that behavioral responses to predation alone were not enough to bring about aspen recovery at a landscape scale. However, predation risk responses such as changes in elk grouping dynamics (White et al. 2012) and habitat selection (Mao et al. 2005) may be driving some of the small-scale variation between stands in the same area, and predation risk may also be a factor in the largescale redistribution of the elk herd (Proffitt et al. 2009). Elk numbers increased in the portion of the Yellowstone northern range outside of the park before the return of wolves, but this did not result in reduced elk densities or reduced herbivory inside park boundaries. The fact that aspen did not recover during a period of low elk population density in the 1950s and 1960s suggests that something more than a simple reduction in elk numbers was needed to reverse the aspen decline.

Our results update and expand knowledge of aspen stand conditions across Yellowstone's northern range. We found that aspen stands have begun to recover relative to conditions before wolf reintroduction, but this recovery is in an early stage and highly variable across the landscape. The reductions in browsing and associated height increases of young aspen were greatest in the eastern part of the range, but within each sector there also was wide local variation. The recent increase in recruitment of aspen saplings was associated with a reduction in browsing, linked most plausibly to the return of wolves and subsequent changes in elk numbers and distribution. The Yellowstone example suggests that wolves could play a role in support of aspen conservation through reduction of herbivory. The complex relationship of wolves, elk and aspen will continue to unfold, interacting with an increasing bison population, warming climate, changes in land use and hunting outside the park, and other facets of the Yellowstone ecosystem.

\section{$\uparrow$ ACKNOWLEDGEMENTS}

This research was supported by a grant from the University of Wyoming - National Park Service Research Center, as was the research of Larsen and Ripple in 1997 used in this analysis. Our thanks to Hank Harlow for hospitality and encouragement. Thanks also to our field technicians Jeff Stephens and Jonathan Batchelor.

\section{LiterATURE Cited}

Barmore WJ. 2003. Ecology of Ungulates and their Winter Range in Northern Yellowstone National Park; Research and Synthesis 19621970. Yellowstone Center for Resources, Yellowstone National Park.

Beschta RL, Ripple WJ. 2011. Are wolves saving Yellowstone's aspen? A landscape-level test of a behaviorally mediated trophic cascade Comment. Ecology doi:10.1890/11-0063.1.

Beschta RL, Ripple WJ. 2007. Wolves, elk, and aspen in the winter range of Jasper National Park, Canada. Canadian Journal of Forest Research 37: 1873-85.

Brodie J, Post E, Watson F, Berger J. 2011. Climate change intensification of herbivore impacts on tree recruitment. Proceedings Royal Society B: Biological Sciences 279: 1366-70.

Eisenberg C, Seager ST, Hibbs DE. 2013. Wolf, elk, and aspen food web relationships: context and complexity. Forest Ecology and Management dx.doi.org/10.1016/j.foreco. 2013.01.014.

Hanna P, Kulakowski D. 2012. The influences of climate on aspen dieback. Forest Ecology and Management 274: 91-98.

Hebblewhite M, White CA, Nietvelt CG, McKenzie JA, Hurd TE, Fryxell JM, Bayley SE, Paquet PC. 2005. Human activity mediates a trophic cascade caused by wolves. Ecology 86: 2135 44.

Kauffman MJ, JF Brodie, ES Jules. 2010. Are wolves saving Yellowstone's aspen? A landscapelevel test of a behaviorally mediated trophic cascade. Ecology 91: 2742-55.

Kay CE. 1990. Yellowstone's northern elk herd: a critical evaluation of the "natural regulation" paradigm. PhD dissertation. Utah State University, Logan.

Kay CE. 2001. Long-term aspen exclosures in the Yellowstone ecosystem. In: Editors,W. Shepperd WD et al. Sustaining Aspen in Western Landscapes: Symposium Proceedings, June 13-15, 2000, Grand Junction, Colorado. RMRS-P-18. USDA Forest Service, Rocky Mountain Research Station, Fort Collins. Pages 225-40. 
Keigley RB, Frisina MR. 1998. Browse evaluation by analysis of growth form. Montana Fish, Wildlife and Parks, Helena. 153p.

Larsen EJ. 2001. Aspen age structure and stand conditions on elk winter range in the northern Yellowstone ecosystem. $\mathrm{PhD}$ dissertation. Oregon State University, Corvallis.

Larsen EJ, WJ Ripple. 2003. Aspen age structure in the northern Yellowstone ecosystem: USA. Forest Ecology and Management 179: 46982.

Larsen EJ, Ripple WJ. 2005. Aspen stand conditions on elk winter ranges in the northern Yellowstone ecosystem, USA. Natural Areas Journal 25: 326-38.

Mao, JS, Boyce MS, Smith DW, Singer FJ, Vales DJ, Vore JM, Merrill EH. 2005. Habitat selection by elk before and after wolf reintroduction in Yellowstone National Park. Journal of Wildlife Management 69: 1691-707.

McMenamin SK, Hadly EA, Wright CK. 2008. Climatic change and wetland desiccation cause amphibian decline in Yellowstone National Park. Proceedings of the National Academy of Sciences 105: 16988-93.

National Research Council. 2002. Ecological Dynamics on Yellowstone's Northern Range. National Academies Press, Washington, DC.

Painter LE, Ripple WJ. 2012. Effects of bison on willow and cottonwood in northern Yellowstone National Park. Forest Ecology and Management 264: 150-58.

Proffitt KM, Grigg JL, Hamlin KL, Garrott RA. 2009. Contrasting effects of wolves and human hunters on elk behavioral responses to predation risk. Journal of Wildlife Management 73: 345-56.

Ripple WJ, Beschta RL. 2006. Linking wolves to willows via risk-sensitive foraging by ungulates in the northern Yellowstone ecosystem. Forest Ecology and Management 230: 96-106.

Ripple WJ Beschta RL. 2007. Restoring Yellowstone's aspen with wolves. Biological Conservation 138: 514-19.

Ripple WJ, Beschta RL. 2012. Trophic cascades in Yellowstone: the first 15 years after wolf reintroduction. Biological Conservation 145: 205-13.

Ripple WJ, Larsen EJ, Renkin RA, Smith DW. 2001. Trophic cascades among wolves, elk and aspen on Yellowstone National Park's northern range. Biological Conservation 102: 227-34.

Romme, WH, Turner MG, Wallace LL, Walker JS. 1995. Aspen, elk, and fire in northern Yellowstone Park. Ecology 76: 2097-106.

Smith DW, Bangs EE. 2009. Reintroduction of wolves to Yellowstone National Park: history, values and ecosystem restoration. Pages 92-125 in M.W. Hayward and M.J. Somers, editors. Reintroduction of Top-Order Predators. Wiley-Blackwell, Oxford.

St. John RA. 1995. Aspen stand recruitment and ungulate impacts: Gardiner Ranger District, Gardiner, Montana. M.S. Thesis. University of Montana, Missoula.

Wagner FH. 2006. Yellowstone's Destabilized Ecosystem: Elk Effects, Science, and Policy Conflict. Oxford University Press, New York. 371p.

White CA, MC Feller, Bayley S. 2003. Predation risk and the functional response of elk-aspen herbivory. Forest Ecology and Management 181: 77-97.

White CA, Olmsted CE, Kay CE. 1998. Aspen, elk, and fire in the Rocky Mountain national parks of North America. Wildlife Society Bulletin 26: 449-62.

White PJ, Proffitt KM, Lemke TO. 2012. Changes in elk distribution and group sizes after wolf restoration. American Midland Naturalist 167: 174-87.

Wilmers CC, Getz WM. 2005. Gray wolves as climate change buffers in Yellowstone. PLoS Biology 3: e92. doi:10.1371/ journal.pbio.0030092.

Yellowstone National Park. 1997. Yellowstone's Northern Range: Complexity and Change in a Wildland Ecosystem. National Park Service, Mammoth Hot Springs. 148p. 